\title{
Weonomics
}

Central European Review of Economics \& Finance

Vol. 23, No. 1 (2018), pp. 5-11

DOI: $10.24136 /$ ceref.2018.001

Received: 10 December 2017. Accepted: 15 January 2018

Pantelis F. KYRMIZOGLOU ${ }^{1}$

\section{GREEK HOTELS: HIGH NPES IN TIMES OF A THRIVING TOURISM}

In this paper we try to show the big problem of non-performing exposures faced by the Greek Banking System and more specifically the particularities of the Greek Hotels, despite the favorable conditions for tourism. Our objective is to draw some conclusions regarding the reasons of the problem.

JEL Classification Codes: L83, Z32.

Keywords: Hotels, Greek economy, Financial crisis.

\section{Introduction}

For more than 7 years now, the Greek economy is struggling to find a way out of the financial crisis. Under normal conditions the banking system would be expected to play a very important role. Unfortunately, the low liquidity and the high percentage of nonperforming loans have a negative impact on the lending criteria of the Greek Banks and consequently on the supply and demand of bank loans.

Some efforts to explain the problem at high figures of non-performing loans, by blaming the banks' wrong lending practices in the period before the crisis, have been rejected by the research made in this field. (Monokrousos et al). It is rather attributed to the long-lasting recession which is not due to the lending practices, but it is connected to the wrong government practices regarding the public debt crisis.

Since 2014 the Bank of Greece adopted the term "non-performing exposures" (NPEs), which is broader than non-performing loans (NPLs). NPEs include all debt instruments as well as off-balance sheet exposures. They include exposures with a de-

\footnotetext{
${ }^{1}$ Professor, Alexander TEl of Thessaloniki.
} 
lay longer than 90 days and besides they include exposures with uncertain collection although they are either performing or are less than 90 days past due. So we can see that qualitative criteria have been added.

The efficient management of non-performing exposures is expected to contribute to the recovery of bank financing and the overall restructuring of entrepreneurship in Greece. High NPEs lead to reduced financial resources and increased rates of interest. By the end of 2016, the non-performing business exposures were amounting $44.4 \%$ of the total business exposures, namely among the highest in the European Union, where the average figure was $5.5 \%$ in June 2016 . The comparison is really impressive with the NPEs in Greece representing 10\% of the total NPEs of EU, whereas the total assets of the Greek Banking Sector is only $1.2 \%$ of total assets of Banks in the EU.

More specifically the respective percentage for the non-performing exposures of SMEs was $58.9 \%$ and for the very small businesses was $68.3 \%$. The problem is relatively smaller for the bigger companies, as the respective figure is $26.7 \%$ (Bank of Greece).

Despite the fact that the Greek Banks have already made sufficient provisions in their balance sheets and they have "satisfactory” collateral (consisting mainly from $81 \%$ real estate), the problem remains with the aforementioned consequences. The bad condition of the real estate market with a $41.9 \%$ fall in the prices of apartments from 2008 until the first quarter of 2017, confirm this argument (Mitrakos 2017). Of course, we have to point out that real estate connected with tourism, proved to be the most resilient in the Greek economy. Especially, in the areas of Attica, Mykonos, Corfu etc, where a considerable number of investments (mainly from abroad) started and it was connected mainly with the construction of new high quality hotels.

It is impressive that the percentage of non-performing exposures for the Tourism Sector reaches $54 \%$, compared with $45 \%$ which is the average of NPEs for all the business loans in 2016.

In the rest of this paper we will try to investigate the reasons leading to this big contradiction. Actually why in a period of „success?” of the Greek Tourism, high percentages of NPEs are recorded, although Tourism is considered as one of the main pillars of growth for the Greek economy. We will do that by referring to the characteristics of the Greek Tourism, which show the pros and cons of the specific industry. The various existing disadvantages lead to the explanation of the contradiction.

\section{Characteristics of the Greek Tourism}

The role of tourism in the Greek economy is crucial. It contributes to the GDP of the country with $18.6 \%$ and to the total employment with $23.4 \%$ (2016). We can see the development of the respective figures in the following table 1 . The market share of the Greek Tourism from 2001 to 2015 ranges at global level from $1.5 \%$ to $2 \%$ and at 
European level from $2.8 \%$ to $3.8 \%$ (table 2). In the next table 3, we can see the Hotel infrastructure of the country with the respective number of hotels and numbers of beds.

Table 1. Participation of Tourism in the GDP and the Employment of the country

\begin{tabular}{|c|c|c|}
\hline Year & \% of GDP & \% of Employment \\
\hline 2000 & 16.6 & 19.2 \\
\hline 2001 & 17.1 & 19.4 \\
\hline 2002 & 16.5 & 19 \\
\hline 2003 & 15.9 & 18.1 \\
\hline 2004 & 16.3 & 18.2 \\
\hline 2005 & 17.6 & 19.5 \\
\hline 2006 & 17.8 & 19.8 \\
\hline 2007 & 17.5 & 19.4 \\
\hline 2008 & 16.8 & 18.7 \\
\hline 2009 & 15.9 & 17.7 \\
\hline 2010 & 16 & 17.8 \\
\hline 2011 & 16.4 & 18.3 \\
\hline 2012 & 16.4 & 18.3 \\
\hline 2013 & 16.3 & 18.2 \\
\hline 2014 & 17.3 & 17.3 \\
\hline 2015 & 18.5 & 23.1 \\
\hline 2016 & 18.6 & 23.4 \\
\hline
\end{tabular}

Source: Bank of Greece.

Table 2. Market Share of the Greek Tourism

\begin{tabular}{|c|c|c|}
\hline Year & World & Europe \\
\hline 2001 & 1.9 & 3.4 \\
\hline 2002 & 1.8 & 3.2 \\
\hline 2003 & 1.8 & 3.1 \\
\hline 2004 & 1.5 & 2.8 \\
\hline 2005 & 1.8 & 3.3 \\
\hline 2006 & 1.8 & 3.3 \\
\hline 2007 & 1.8 & 3.3 \\
\hline 2008 & 1.7 & 3.3 \\
\hline 2009 & 1.7 & 3.2 \\
\hline 2010 & 1.6 & 3.1 \\
\hline 2011 & 1.5 & 2.9 \\
\hline 2012 & 1.5 & 2.9 \\
\hline 2013 & 1.6 & 2.9 \\
\hline 2014 & 1.8 & 3.8 \\
\hline 2015 & 2 & 3.1 \\
\hline
\end{tabular}

Source: SETE. 
Table 3. Hotel Infrastructure of the country

\begin{tabular}{|c|c|c|}
\hline Year & Number of Hotels & Number of Beds \\
\hline 2000 & 8073 & 593999 \\
\hline 2001 & 8285 & 608104 \\
\hline 2002 & 8527 & 626914 \\
\hline 2003 & 8689 & 644898 \\
\hline 2004 & 8899 & 668271 \\
\hline 2005 & 9036 & 682050 \\
\hline 2006 & 9111 & 693252 \\
\hline 2007 & 9207 & 700933 \\
\hline 2008 & 9385 & 715857 \\
\hline 2009 & 9554 & 726546 \\
\hline 2010 & 9732 & 763407 \\
\hline 2011 & 9670 & 771271 \\
\hline 2012 & 9670 & 771271 \\
\hline 2013 & 9677 & 773445 \\
\hline 2014 & 9851 & 792304 \\
\hline 2015 & 9757 & 784315 \\
\hline 2016 & 9730 & 788553 \\
\hline
\end{tabular}

Source: Hotel Chamber of Greece.

The Greek Tourism is characterized by a high concentration in the supply of hotel beds, with $70 \%$ of them being offered in 4 out of the 13 regions of the country. (More specifically the regions of Southern Aegean, Crete, Central Macedonia, and Ionian Islands offer $70 \%$ number of beds). (SETE 2016)

Five regions of the country benefit $87.5 \%$ of the total receipts from tourism. More specifically the five regions are:

- Southern Aegean;

- Crete;

- Attica;

- Central Macedonia;

- Ionian Islands;

- in order of magnitude of the respective receipts (Bank of Greece).

The Greek Tourism is characterized by high seasonality. The highest number of foreign tourism arrivals takes place in July, August and September, with the highest figure $(56 \%)$ recorded in 2016 and the lowest (47.7\%) recorded in 2007 (table 4).

In the next table 5, we can see that the spectacular increase in the arrivals of foreign tourists is not accompanied by a respective spectacular increase in receipts. But it is the gradually diminishing expenditure per capita that creates a lot of worries for the future of tourism and the Greek hotels. 
Table 4. Arrivals of foreign tourists in July, August and September as \% of total arrivals

\begin{tabular}{|c|c|}
\hline Year & Percentage \\
\hline 2001 & 51.3 \\
\hline 2002 & 50.3 \\
\hline 2003 & 50.6 \\
\hline 2004 & 49.1 \\
\hline 2005 & 49.5 \\
\hline 2006 & 49 \\
\hline 2007 & 47.7 \\
\hline 2008 & 50 \\
\hline 2009 & 52 \\
\hline 2010 & 55 \\
\hline 2011 & 56 \\
\hline 2012 & 56 \\
\hline 2013 & 56 \\
\hline 2014 & 56 \\
\hline 2015 & 55 \\
\hline 2016 & 56 \\
\hline
\end{tabular}

Source: SETE.

Table 5. Foreign tourists' arrivals, receipts and expenditure per capita

\begin{tabular}{|c|c|c|c|}
\hline Year & $\begin{array}{c}\text { Arrivals } \\
\text { (in millions) }\end{array}$ & $\begin{array}{c}\text { Receipts } \\
\text { (in bn euros) }\end{array}$ & $\begin{array}{c}\text { Expenditure } \\
\text { per capita in euros }\end{array}$ \\
\hline 2001 & 13 & 10.6 & 810 \\
\hline 2002 & 12.6 & 10.3 & 819 \\
\hline 2003 & 12.5 & 9.5 & 762 \\
\hline 2004 & 11.7 & 10.4 & 882 \\
\hline 2005 & 14.4 & 10.7 & 746 \\
\hline 2006 & 15.2 & 11.4 & 746 \\
\hline 2007 & 16.2 & 11.3 & 700 \\
\hline 2008 & 15.9 & 11.6 & 730 \\
\hline 2009 & 14.9 & 10.4 & 697 \\
\hline 2010 & 15 & 9.6 & 640 \\
\hline 2011 & 16.9 & 10.4 & 616 \\
\hline 2012 & 16.9 & 10.4 & 616 \\
\hline 2013 & 17.9 & 11.7 & 653 \\
\hline 2014 & 22 & 13 & 590 \\
\hline 2015 & 23.6 & 13.6 & 580 \\
\hline 2016 & 24.7 & 12.7 & 514 \\
\hline
\end{tabular}

Source: Bank of Greece. 


\section{Factors leading to high NPEs of the Greek Hotels}

The difficulties faced by the hotel industry in Greece can be confirmed by a recent report of PWC. Among other observations, the report refers to the fact that the Greek hotel industry relies mainly on small hotels. The 2 stars hotels constitute about $45 \%$ of the total figure. There are only 367 hotels with more 300 beds, representing $4 \%$ of the total number and $25 \%$ of the total bed capacity. The hotel industry is split and the average size of a hotel is 247 beds. Finally, the PWC report suggests three strategies for investments in hospitality:

1. Adding capacity in main destination by using unutilized building permits.

2. Upgrading hotels to the next class.

3. Developing lesser destinations by the acquisition of many hotels at one of them. This is considered the most promising strategy.

The objective of this paper is to investigate and find out the reasons leading to the high NPEs for the Greek Hotels.

Most of the reasons are common with the rest sectors of the Greek economy. We noticed in the beginning of the paper that the non-performing exposures are higher for the smaller companies. This is also valid for the smaller hotels which constitute the majority of the Greek hotels. If we take into account the above mentioned characteristics of the Greek Tourism, the report of PWC and the research carried out by various authors, we can reach certain conclusions regarding the recorded high NPEs of the Greek Hotels. More specifically the high NPEs of the Greek hotels are connected with:

- The big number of small hotels.

- The high seasonality of the demand of hotel services.

- The decreasing receipts from tourism, despite the increasing number of tourists arrivals.

- The decreasing tourist expenditure per capita.

- The spread of all inclusive tourism.

- The strong presence of rooms to let (very often being part of the big underground economy and therefore competing with the hotels with unequal terms).

- The spread of Airbnb, gaining market share against the Greek hotels.

- The high taxation on hotels' earnings (51.7\% for taxes and social security contributions, compared with $40.1 \%$ average rate for the developed countries of OECD) (Doing Business 2018).

- The weakness of Greek Hotels to attract tourists with higher income per capita connected with the relatively low competitiveness of the Greek Tourism ( which is not necessarily attributed to the Greek Hotels, but it can be associated with taxi drivers, travel agents, museum trade unions etc). 


\section{Concluding remarks}

All the above-mentioned factors constitute a very complicated business environment for the Greek Hotels and, in our opinion, create serious difficulties in the Hotels' ability to pay out their debts to the Banks. The solution of the problem depends on the governments' determination to tackle the problems by establishing a modern, transparent, fair and efficient institutional framework.

On the other hand we should not underestimate the hotel owners' lack of willingness to proceed to reforms connected with the cost, the price and the quality of their services.

We believe that under the current conditions the problems will remain, even if the very optimistic forecasts for 30 million foreign tourists arrival in the next years, comes true. The need for upgrading the quality first and the quantity second in the hotel infrastructure of the country is imperative.

\section{References}

Maroulis D., Ikkos A. (2016). Greek Tourism developments - perspectives. Vol. I, July 2016, INSETE.

Mitrakos T. (2016). Diahirisi mi exipiretoumenon danion: proklisi gia tin epistrofi stin anaptyxi. University of Athens, 29/2/2016.

Mitrakos T. (2016). Financing the economy: the way forward. $11^{\text {th }}$ Red Business Forum „Bridging the Gap".

Mitrakos T. (2017). Incentives for Growth. 12 ${ }^{\text {th }}$ Red Business Forum, 30/5/2017.

Monokrousos P., Thomakos D., Alexopoulos T. (2016). High NPEs Ratio in Greece: Outcome of an unprecedented recession or the lending practices of domestic credit institutions in the precrisis era? Eurobank Global Market Research (May 2016).

PWC. (2016). Hotel Investment Strategies in Greece. PWC Report, Feb. 2016.

Souki S. (2017). Ta Kokkina dania ton xenodohon, www.insidestory.gr .

World Bank: Doing Business 2018.

World Travel \& Tourism Council (2017). Travel \& Tourism Economic Impact 2017 Greece.

www.bankofgreece.gr

www.sete.gr 